\title{
KONFLIK SOSIAL SUKU ANAK DALAM (ORANG RIMBA) DI PROVINSI JAMBI
}

\author{
Wandi \\ STIE Syari'ah Al-Mujaddid, Jambi \\ huseinwandi220@gmail.com
}

\begin{abstract}
This article aims to explore the social conflicts in the utilization of natural resources of the Anak Dalam or Orang Rimba tribes. The purpose of this study is to find out the cause of social conflict that occurred. The research method used is a qualitative method based on literature studies and interviews as well as the accumulation of understanding from various primary studies conducted on the Suku Anak Dalam or Orang Rimba community. The results of this study are, first, there are differences in perceptions regarding regional claims between the state, companies, surrounding villagers, as well as Suku Anak Dalam or Orang Rimba. Secondly, there is a conflict of interest in the utilization of forest resources that were previously home to the Anak Dalam or Orang Rimba tribes. Third, there is competition in the use of forest resources. Fourth, it is a dilemma for Suku Anak Dalam or Orang Rimba in the midst of the development of the times, where they have lived for a long time, and have collided with policies that are oriented towards group interests. This study is expected to be able to provide an overview of the conflicts and to provide solutions to the rights and survival of the Suku Anak Dalam or Orang Rimba communities.
\end{abstract}

Keywords: natural resources, social conflict, Suku Anak Dalam

\begin{abstract}
Abstrak
Artikel ini bertujuan mengali lebih dalam mengenai konflik sosial pemanfaatan sumber daya alam Suku Anak Dalam atau Orang Rimba. Tujuan penelitian ini adalah untuk mencari tahu penyebab konflik sosial itu terjadi. Metode penelitan yang digunakan adalah metode kualitatif berdasarkan studi literatur dan wawancara serta akumulasi pemahaman dari berbagai studi primer yang dilakukan pada masyarakat Suku Anak Dalam atau Orang Rimba. Hasil penelitian ini adalah, pertama, adanya perbedaan persepsi mengenai klaim wilayah
\end{abstract}


antara negara, perusahaan, warga desa sekitar, maupun Suku Anak Dalam atau Orang Rimba. Kedua, adanya benturan kepentingan dalam pemanfaatan sumber daya hutan yang memang sebelumnya rumah bagi Suku Anak Dalam atau Orang Rimba. Ketiga, adanya persaingan dalam pemanfaatan sumber daya hutan. Keempat, merupakan dilema bagi Suku Anak Dalam atau Orang Rimba ditengah perkembangan zaman, tempat tinggal yang sudah lama mereka tempati terbentur dengan kebijakan-kebijakan yang berorientasi pada kepentingan kelompok. Studi ini diharapkan dapat memberi gambaran atas konflik yang terjadi serta memberikan solusi atas hak dan keberlangsungan hidup masyarakat Suku Anak Dalam atau Orang Rimba.

Kata Kunci: konflik sosial, sumber daya alam, Suku Anak Dalam

\section{PENDAHULUAN}

Hutan adalah salah satu sumber daya alam yang penting baik bagi negara bagi masyarakat. Bagi negara, hutan merupakan salah satu devisa non migas yang telah banyak memberikan kontribusi bagi pelaksanaan pembangunan nasional. Sedangkan bagi masyarakat khususnya yang bermukim di sekitar kawasan hutan, hutan merupakan cadangan lahan bagi perluasan areal pertanian dan penyuplai kebutuhan kayu dan non kayu.

Pada tahun 2009 dilaporkan bahwa sekitar 2,3 juta hektar kawasan jelajah masyarakat Suku Anak Dalam atau Orang Rimba di Provinsi Jambi telah berubah menjadi perkebunan sawit, hutan tanaman industri (akasia), areal hak penguasaan hutan, pemukiman transmigrasi. Akibatnya, orang Rimba makin terpojok mendapatkan sumbersumber makanan dalam hutan yang juga tempat mereka tinggal selama ini.

Eksistensi Suku Anak Dalam atau Orang Rimba jelas dewasa ini menjadi terancam akibat gerusan zaman dan arus perubahan, terutama perubahan kebijakan yang dilakukan oleh pemerintah. Dalam kebijakan tersebut seakan-akan pemerintah ikut- ikutan mengatur dan ikut campur lebih dalam mengenai kehidupan Suku Anak Dalam atau Orang Rimba, dalam hal ini tentu menjadi ancaman tersendiri bagi eksistensi mereka terutama kebijakan mengenai pengelolaan hutan, karena bagi mereka kehidupan mereka adalah hutan tersebut.

Orang Rimba mempunyai aturan adat dalam menjaga kelestarian dan keberlangsungan hutan di provinsi Jambi, dengan aturan adat tersebut mereka memanfaatkan hasil hutan sebagai sumber ekonomi, disamping itu ragam tradisi dan budaya menjadi kearifan tersendiri dalam kehidupan hutan mereka, dan semua kearifan tradisi dan adat istiadat sebagai identitas tersebut berjalan seiring proses alamiah kehidupan yang mereka jalani.

Masyarakat Suku Anak Dalam atau Orang Rimba merupakan bagian dari kelompok masyarakat terasing yang berada di wilayah Provinsi Jambi dengan populasi seluruhnya 200.000 orang yang tersebar di beberapa kabupaten di Provinsi Jambi terkhusus wilayah mudik Provinsi Jambi, yaitu Kabupaten Batang Hari, Kapubaten Bungo, Kabupaten Tebo, Kabupaten Sarolangun, Kabupaten 
Bangko (BPS, 2018). Mereka hidupnya terpencil, terisolasi, tertinggal dibidang ekonomi, politik, kesehatan dan sosial.

Untuk diketahui kawasan hutan Suku Anak Dalam atau Orang Rimba saat ini luas dan areanya, sisanya adalah kawasan hutan yang berstatus hutan kawasan. Belum lagi okum-oknum yang merasa berkepentingan dan mengambil keuntungan terhadap kawasan hutan semakin banyak yang pada akhirnya melahirkan kompetisi yang sengit akibat keserakahan umat manusia, kasus ini utamanya berada dikawasan hutan terutama hutan nasional bukit dua belas.

Kejadian di atas mengambarkan terutama di Indonesia yang merupakan basis agraris menjadikan kawasan hutan sebagai primadona dan rebutan dari berbagai pihak bahkan negara sekalipun atau pihak swasta, yang biasanya mereka gunakan untuk perkebunan sawit, kawasan pemukiman transmigrasi, bahkan sampai pada ekspansi lahan pertanian serta ekspoitasi sumber daya kayu dan non kayu dalam hal ini siapa yang dirugikan, tentu pihak Suku Anak Dalam atau Orang Rimba.

\section{METODE}

Artikel ini ditulis berdasarkan studi literatur dan wawancara serta akumulasi pemahaman dari berbagai studi primer yang dilakukan pada Suku Anak Dalam atau Orang Rimba. Pengumpulan data dilakukan melalui metode wawancara mendalam terhadap sejumlah narasumber dan informan kunci serta observasi lapangan. Narasumber yang diwawancarai meliputi Suku Anak Dalam, warga setempat dan perusahaan yang beroperasi di Taman Nasional Bukit Duabelas. Informan kunci terdiri dari orang-orang yang banyak mengetahui dan memahami permasalahan tentang konflik sosial Suku Anak Dalam atau Orang Rimba. Analisis yang dikembangkan dalam penelitian ini adalah analisis kualitatif, yaitu dengan melakukan pemahaman yang komprehensif. Pemahaman yang komprehensif ini menempatkan objek kajian dalam konteks hubungan kausalitas, dan konsep empati sebagai pendekatan. Pendekatan empati yang dimaksud adalah pendekatan yang berupaya memahami permasalahan penelitian dari perspektif pelaku.

\section{III.HASIL DAN \\ PEMBAHASAN}

Masyarakat asli Suku Anak Dalam atau Orang Rimba telah mendiami hutan Provinsi Jambi selama ratusan tahun. Komunitas Orang Rimba menyebut hutan yang ada di Provinsi Jambi sebagai daerah pengembaraan: dimana mereka berinteraksi dengan alam, saling memberi dan menerima dan saling menghidupi. Untuk memenuhi kebutuhan hidupnya, Orang Rimba melakukan kegiatan berburu, mencari ikan, mencari madu, dan menyadap karet untuk dijual (Fahmi, 2006).

Dari beberapa referensi diatas dapat penulis katakan bahwa Orang Rimba Provinsi Jambi merupakan salah satu suku asli yang telah lama bermukim di Jambi, namun lambat laun dan pergerusan zaman akibat dominasi kekuasaan ikut mempengaruhi pelabelan dalam penyebutan kelompok minoritas ini, setiap kelompok yang telah melakukam interaksi dengan mereka akan memberikan penamaan yang berbeda, untuk penamaan ini, kata Suku 
Anak Dalam atau Orang Rimba adalah sebutan yang lazim yang digunakan dalam tataran ilmuan, tetapi masyarakat umum, khususnya masyarakat Provinsi Jambi lebih sering menggunakan kata Suku Kubu atau Orang Kubu.

Masyarakat Orang Rimba itu sendiri sangat tidak suka apabila mereka disebut Orang Kubu atau Suku Kubu, menurut mereka penamaan ini dianggap sangat kasar karena mengidentifikasikan keterbelakangan dan kebodohan. Padahal, makna dari kata Kubu itu sendiri berarti pemertahanan: yaitu orang yang bertahan hidup di hutan atau bisa juga diartikan sebagai benteng (Rozelin, 2014). Masyarakat Orang Rimba awalnya hidup berpindah-berpindah dari satu wilayah ke wilayah yang lain di dalam hutan, di kawasan hutan mereka hidup secara berkelompok dan menyebar ke beberapa kabupaten seperti di Kabupaten Tebo, Kabupaten Bungo, Kabupaten Muara Jambi, Kabupaten Merangin dan Kabupaten Sarolangun.

Berdasarkan tempat tinggal dan pakaian, kelompok Orang Rimba dapat diklasifikasikan ke dalam tiga kategori pemukiman (Sutumo, 1995). Pertama, Orang Rimba yang bermukim di dalam hutan dan hidup berpindah-pindah. Kedua, Orang Rimba yang hidup dalam hutan dan menetap. Ketiga, Orang Rimba yang pemikimannya berdekatan dengan pemukiman Orang Terang (masyarakat umum. Jika diamati dari segi pakaian, Orang Rimba telah banyak mengalami perubahan, tetapi yang masih menetap didalam hutan dan hidupnya berpindahpindah mereka masih mempertahankan pakaian tradisional mereka.

Suku Orang Rimba Provinsi Jambi merupakan pecinta hutan sejati, mereka senantiasa menggunakan seluruh ruang didalam hutan sebagai tempat membangun interaksi sosial sesama komunitas Orang Rimba. Kepercayaan, adat dan tradisi muncul dari proses interaksinya dengan hutan, bagi mereka hutan bukan saja diartikan sebagai sumber kehidupan, akan tetapi juga merupakan simbol sebuah kepercayaan, merubah hutan berarti merubah kodrat tuhan maka akan timbul kerusakan hutan, tidak ada lagi binatang buruan, sumber daya hutan lainnya akan sulit ditemukan akhirnya berdampak pada sumber perekonomian.

Keberadaan Orang Rimba saat ini adalah keberadaan yang terancam terhadap arus perubahan yang ingin dilakukan negara. Kebijakan pemerintah mengatur dan ikut campur dalam kehidupan Orang Rimba tentu menjadi ancaman tersendiri bagi ekosistem mereka, karena bagi Orang Rimba kehidupan mereka adalah hutan, Orang Rimba mempunyai aturan adat dalam menjaga kelestarian dan keberlangsungan hutan dengan aturan adat tersebut mereka memanfaatkan hasil hutan Provinsi Jambi sebagai sumber ekonomi kehidupan, disamping itu ragam tradisi budaya menjadi kearifan tersendiri dalam kehidupan hutan mereka, dan semua kearifan tradisi dan adat istiadat sebagai identitas tersebut berjalan seiring dengan proses alamiah kehidupan hutan yang mereka jalani (Sentosa, 2011).

\subsection{Konflik-Konflik Sumber Daya Alam di Provinsi Jambi}

Sejak tahun 1970, sumber daya Bukit Dua Belas Provinsi Jambi telah menjadi rebutan arena konflik horizontal maupun vertikal. Kebijakan pengelolaan 
hutan yang memberi izin HPH pada perusahaan tidah hanya menambah jumlah kompetitor dalam pemanfaatan sumber daya hutan tetapijuga mendorong pergeseran paradigma pemanfaatan sumber daya hutan oleh warga desa dari tujuan pemenuhan kehidupan hidup dalam hal ini kegunaan kayu untuk bahan bangunan yang pada akhirnya menjadi komersialisi hasil hutan terutama hutan kayu karena memang harganya cukup mahal. Sejak tahun 1970 pula warga desa secara perlahan banyak berganti profesi dari yang mulanya petani biasa akhirnya menjarah hutan illegal loging atau disini disebut bebalok (wawancara dengan Orang Rimba Salb).

Pekerjaan bertani seperti menyadap karetdansawityangmerupakanpekerjaan mayoritas penduduk di Provinsi Jambi lamban naun mereka tinggalkan, karena menggap bahwa illegal loging jauh lebih menjajikan untuk masa depan yang lebih baik. Warga mengekspresikan zaman kayu maksud mereka illegal logging adalah zaman kemakmuran, pada saat itu pulalah warga menganggap bahwa kawasan itu adalah kawasan open acces meskipun secara legal hutan tersebut berada kawasan hutan lindung milik Negara yang di kelola perusahaan.

Hukum-hukum adat yang mengatur pemanfaatan sumber daya hutan secara perlahan mulai ditinggalkan, demikian pula kesepakatan-kesepakatan mengenai batas wilayah akses antara warga desa dan Suku Anak Dalam atau Orang Rimba yang sebelumnya di jaga, juga secara perlahan mulai dikaburkan karena dorongan untuk menguasai sumber hutan yang ada.

Seiring dengan semakin banyaknya warga desa yang melakukan aktivitas illegal logging yang di dorong oleh para pemilik modal, gesekan konflik antar warga Suku Anak Dalam muncul ke permukaan. Ini dikarenakan terlalu lamanya perambahan hutan atau illegal loging yang dilakukan oleh warga setempat yang akhirnya mendesak Suku Anak Dalam atau Orang Rimba ikut marah.

Konflik antar kelompok yang melakukan aktivitas illegal logging terjadi karena penyerobotan wilayah blok tebangan. Sebenarnya para pelaku illegal logging tersebut memilik aturan dalam menentukan blok tebangan yaitu dengan cara memberi tanda pada pohon-pohon kayu yang akan ditebang sebagai simbol klaim atau tanda ataupun dengan cara membuat rintisan tebangan di sekeliling areal blok tebangan.

Namun, sering kali tanda klaim kayu tebangan atau rintisan tersebut tidak kelihatan sehingga terjadi kesalah pahaman, bentuk-bentuk penyelesaian konflik semacam ini biasanya dilakukan melalui negoisasi atau perundingan dan pihak yang melakukan penyerobotan diwajibkan membayar ganti rugi senilai pohon kayu yang telah diambil.

Konflik tersebut menyisakan banyak masalah, baik konflik antar sesama warga desayang melakukan illegallogging, belum lagi konflik antara warga desa dengan Suku Anak Dalam atau Orang Rimba. Ini dikarenakan warga desa yang melakukan illegal logging menyebabkan kerusakan hutan dan pohon pada wilayah-wilayah yang dilindungi (dianggap sakral Orang Rimba), dan pada akhirnya warga desa diwajibkan membayar ganti rugi (denda adat).

Gesekan-gesekan konflik ini di perparah karena ada sebagian warga 
desa enggan membayar ganti rugi (denda adat) yang diwajibkan oleh Suku Anak Dalam, dengan alasan berasalan tidak mengetahui bahwa ada pohon-pohon yang di anggap sakral Orang Rimba, dan menganggap bahwa hutan ini milik sama-sama dan tidak ada klaim sepihak seperti yang dianggap Suku Anak Dalam atau Orang Rimba.

Jenis-jenis konflik sebagaimana di utarakan tersebut merupakan merupakan konflik manifes berskala kecil, artinya pihak-pihak yang terlihat konflik merupakan kelompok-kelompok kecil. Konflik yang terpusat pada masalah akses terhadap sumber daya hutan, klaim-klaim wilayah kelompok hanya merupakan instrument untuk membuka akses kelompok dan upaya menutup akses kelompok lain terhadap kawasan tersebut.

Disamping konflik berskala kecil, dijumpai pula adanya konflik berskala besar yang pernah terjadi sehubungan dengan pemanfaatan sumber daya hutan di bukit duabelas provinsi Jambi, yaitu konflik antar warga desa dengan Suku Anak Dalam atau Orang Rimba, dan konflik antar Suku Anak Dalam atau Orang Rimba itu sendiri. Kedua konflik ini juga erat kaitannya dengan masalah akses terhadap sumber daya hutan, namun karakteristik konflik (penyebab, dinamika, dan akibatnya) berbeda.

\subsubsection{Kasus Konflik Kelompok Suku Anak Dalam atau Orang Rimba versus Warga Desa Sei Ruas Ulu}

Konflik lain soal pemanfaatan sumber daya hutan adalah bentrok fisik antara warga desa setempat yaitu warga Desa Sei Ruan Ulu dengan kelompok
Suku Anak Dalam atau Orang Rimba pada tahun 1997. Bentrok ini menyebabkan tewasnya dua orang kelompok Suku Anak Dalam atau Orang Rimba yang ada di dalam kawasan hutan, tempatnya berjarak sekitar $16 \mathrm{~km}$ dari pinggiran sungai Batanghari atau pusat Desa Sungai Ruan dalam hal ini warga menyebutnya di km 16. Konflik yang berakhir bentrok ini melibatkan warga desa yang sering melakukan illegal logging, penebangan liar yang diperkirakan jumlahnya mencapai 100 orang (wawancara dengan Orang Rimba Kupik dan Ali).

Dalam hal Suku Anak Dalam atau Orang Rimba yang terlibat bentrok dengan warga adalah kelompok Temenggung Kecik yang tinggal di kawasan hutan tepat di Desa Sei Ruan Ulu, menurut informasi mereka yang terlibat bentrok diperkirakan ada sekitar 40 orang yang semuanya adalah lakilaki dewasa. Bentrok fisik terjadi selama dua hari, pada hari pertama warga desa melakukan penyerangan ke dalam hutan dan mendapat perlawanan dari Suku Anak Dalam atau Orang Rimba, mengingat jumlah warga desa jauh lebih banyak dan Suku Anak Dalam atau Orang Rimba merasa tidak sanggup menghadapinya, maka Orang Rimba bersembunyi ke dalam hutan waktu itu.

Dalam pristiwa konfrontasi ini banyak warga desa yang ikut dalam bentrok mengalami luka-luka, beberapa harikemudian, warga kembalimelakukan penyerangan, sewaktu masuk hutan, warga desa menjumpai dua orang Suku Anak Dalam tengah mencari ikan dan langsung dikeroyok hingga tewas.

Meskipun masalah tersebut di atas dapat diselesaikan melalui negoisasi atau perundingan, tapi tidak bisa dipungkiri 
konflik tersebut dapat pula berpengaruh pada hubungan sosial antara warga desa dan Suku Anak Dalam atau Orang Rimba serta berdampak pada percepatan degradasi sumber daya hutan akibat deregulasi yang menjadikan kawasan hutan sebagai wilayah kawasan open acces. Hal ini ditunjukkan oleh putusnya hubungan perjenangan Suku Anak Dalam atau Orang Rimba ke Desa Sei Ruan dan aktivitas illegal logging oleh warga desa tidak lagi mengenal batasbatas yang dulu pernah disepakati.

\subsubsection{Kasus Konflik Kelompok Temenggung Jelitai dengan Kelompok Temenggung Majid}

Bentrok fisik antara kelompok Temenggung Jelitai dan Temenggung Majid terjadi hari jum'at tanggal 12 Desember 2008 sekitar pukul 08.00 WIB di hutan dekat Singosaro Desa Pematang Kabau, Kecamatan Air Hitam, Kabupaten Sarolangun. Bentrok fisik berawal dari kedatangan rombongan kelompok Temenggung Jelitai untuk membicarakan masalah penyelesaian kasus pemukulan terhadap orang tua Temenggung Jelitai yang dilakukan oleh anak buah kelompok Temanggung Majid. Sebelum sampai ke tempat Temenggung Majid, di tengah jalan rombongan kelompok Temenggung Jelitai dihadang oleh kelompok Temenggung Madjid dan terjadi bentrok fisik yang mengakibatkan tiga orang korban tewas, dua dari pihak kelompok Temenggung Majid dan satu orang dari pihak kelompok Temenggung Jelitai (wawancara dengan Orang Rimba Kupik dan Ali).

Konflik ini sebenarnya sudah berlangsung lama yaitu sekitar tiga tahun hingga kejadian konflik fisik terjadi pada
12 Desember 2008, sebenarnya antara Temenggung Jelitai dan Temenggung Majid memiliki hubungan kekeluargaan yang sangat dekat. Orang tua perempuan Temenggung Jelitai dan Temenggung Majid adalah saudara (kakak-beradik) dan pihak-pihak yang menjadi korban masing-masing memiliki hubungan sosial yang dekat dari ikatan perkawinan dalam kelompok.

Konflik ini menjelaskan bahwa di internal Orang Rimba tampaknya nilainilai materil dianggap menempati posisi penting ketimbang sebuah hubungan kekeluargaan, akses terhadap sumber daya hutan dipandang lebih mampu menjamin aspek keberlangsungan kebutuhan hidup disbanding ikan sosial antar kelompok.

\subsubsection{Kasus Konflik Sumber Daya Alam Taman Nasional Bukit Dua Belas (TNBD)}

Dari awal sejak diangkatnya isu ini menjadi sebuah tulisan adalah, adanya permasalahan dan koflik sosial atas dalih pemanfaatan sumber daya hutan di sekitar kawasan Bukit Dua Belas yang memang mayoritas Suku Anak Dalam atau Orang Rimba tinggal di kawasan tersebut, sejatinya juga konflik-konflik tersebut di dominasi oleh perusahaan $\mathrm{HPH}$ yang disebut menyerobot rumah sekaligus lahan milik Suku Anak Dalam atau Orang Rimba di dalam kawasan hutan tersebut, dari sini kita ketahui bahwa tingginya gesekan konflik tersebut disebabkan bahwa masing-masing kedua belah pihak sama-sama pengguna dan pemakai kawasan hutan pada saat itu.

Tentu kedahadiran perusahaan HPH menjadi ancaman bagi kehidupan Suku Anak Dalam atau Orang Rimba, 
yang memang sudah terlebih dahulu tinggal dan memanfaatkan sumber daya hutan di sekitar kawasan hutan bukit dua belas. Apalagi semenjak kehadiran perusahaan sekitar tahun 1970 yang memperoleh izin $\mathrm{HPH}$ dalam kawasan yang juga di tempati Suku Anak Dalam atau Orang Rimba, mereka di anggap telah menyebabkan kerusakan-kerusakan sumber daya hutan yang sebelumnya di tempati dan di lindungi Suku Anak Dalam atau Orang Rimba. Akibat kerusakan-kerusakan tersebut akhirnya perusahaan diharuskan membayar ganti rugi sesuai dengan tuntutan Suku Anak Dalam atau Orang Rimba.

Pada masa-masa perusahaan $\mathrm{HPH}$ beroperasi disekitar kawasan hutan bukit duabelas, sebenarnya warga desa juga banyak melakukan aktivitas illegal logging dan sebagian lokasinya mencakup area konsesi perusahaan. Ketengan-ketengan juga muncul antara warga desa yang melakukan aktivitas illegal logging dengan perusahaan namun hanya bersifat konflik laten. Perusahaan lebih memilih menghindari konflik dengan warga desa dengan cara mengalihkan konflik.

Perusahaan menjalin kerja sama dengan Orang Rimba dengan memberikan kompensasi sehingga secara tidak langsung Orang Rimba difungsikan untuk mengamankan areal konsensi perusahaan sehingga yang terlibat konflik pada akhirnya adalah Orang Rimba dengan warga desa (seperti kasus konflik warga Sungai Sei Ruan Ulu dengan Orang Rimba).

Setelah era HPH berakhir dan terjadi perubahanstatuskawasanmenjadiTNBD, otoritas Suku Anak Dalam atau Orang Rimba dalam pemanfaatan kawasan seolah-olah memperoleh legitimasi secara formal. Salah satu butir pertimbangan dalam surat putusan pertunjukan TNBD adalah keberadaan Orang Rimba dalam kawasan yang kehidupannya semakin terdesak. Di kemudian hari, perubahan status kawasan menjadi taman nasional ternyata menjadi sumber masalah bagi keberadaan Suku Anak Dalam atau Orang Rimba dalam kawasan.

Pola pemanfaatan dan pengaturan ruang yang selama ini ditetapkan oleh Suku Anak Dalam atau Orang Rimba ternyata tidak menjadi rujukan dalam konsep pengelolaan TNBD. Pihak pengelola TNBD yang waktu itu di bawah BKSDA (Balai Koservasi Sumberdaya Alam) Jambi mengeluarkan rancangan pengelolaan TNBD yang di dalamnya turut mengatur tentang sistem zonasi kawasan.

Penyusunan rancangan pengelolaan TNBD yang dilakukan secara sepihak oleh BKSD Jambi mendapat penolakan dari Suku Anak Dalam atau Orang Rimba. Orang Rimba memandang bahwa penetapan sistem zonasi dalam pengelolaan TNBD akan membatasi ruang gerak mereka yang sudah terbiasa hidup bebas mengembara dalam hutan kawasan hutan TNBD.

Konflik manifes pun terjadi ketika Suku Anak Dalam atau Orang Rimba memposisikan BKSD Jambi sebagai musuh bersama. Konflik ini kemudian dan berkembang menjadi konflik muntidemensional dengan keterlibatan faktor lain dari lembaga swadaya masyarakat LSM.

Sejarah panjang perubahan status kawasan hutan sekitar bukit duabelas sampai menjadi kawasan TNBD menciptakan pertentangan seputar otoritas pengelolaan dan legitimasi 
penguasaan kawasan di antara Balai TNBD. Suku Anak Dalam atau Orang Rimba dan warga desa. Balai TNBD adalah lembaga yang memperoleh legitimasi dan otoritas pengelolaan kawasan secara formal mewakili (representasi penguasaan oleh negara).

Artinya, secara formal Balai TNBDlah yang paling berhak menentukan arah dan pola pengelolaan TNBD. Suku Anak Dalam atau Orang Rimba yang sudah menempati kawasan secara turun temurun juga merasa memiliki otoritas dalam mengelola kawasan. Warga desa yang dihadapkan pada realitas ketidakjelasan batas-batas desa secara definitif pasca peralihan dari marga ke desa, tetap mengacu pada batas-batas marga dalam mendefinisikan wilayah desa sehingga sebagian kawasan TNBD diklaim masih menjadi bagian dari wilayah desa.

Dalam bahasan mengenai otoritas pengelolaan dan legitimasi penguasaan kawasan hutan sekitar bukit duabelas, pertentangan antara warga desa dengan pihak balai TNBD belum muncul dipermukaan. Hal ini dikarekan warga desa lebih memahami posisi keberadaan hutan negara baik yang berstatus hutan produksi maupun hutan konservasi. Munculnya klaim wilayah yang didasari batas-batas marga hanyalah strategi untuk melegalkan aktivitas pemanfaatan sumber daya hutan yang sebenarnya juga tidak begitu jelas sebagaimana yang telah diuraikan sebelumnya.

Sasarannya adalah areal-areal konsensi perusahaan yang dinilai tingkat resikonya kecil dibandingkan dengan kawasan konservasi. Hal ini telah pula menciptakan konflik vertikal yang bersifat laten antara warga desa dengan pihak perusahaan. Berbeda halnya dengan warga desa, Suku Anak Dalam atau Orang Rimba yang hidup bermukim dalam kawasan. Masalah otoritas pengelolaan dan legitimasi penguasaan kawasan dinilai sangat penting karena berkenaan dengan masa depan dan kelangsungan akses mereka terhadap sumber daya hutan dalam kawasan TNBD.

Perdebatan masalah otoritas pengelolaan dan legitimasi penguasaan kawasan lebih terpusat antara Suku Anak Dalam atau Orang Rimba dan pihak pemegang otoritas formal pengelolaan TNBD yang menempatkan keduanya pada posisi konflik manifest.

Konflik tersebut dulunya tidak mendapat penyelesaian yang baik dan berakhir seiring dengan pergantian rezim pengelolaan kawasan TNBD dari BKSDA Jambi ke balai TNBD. Dengan demikian, pihak balai TNBD sebenarnya telah mewarisi konflik dengan Suku Anak Dalam atau Orang Rimba meskipun sekarang masih berwujud konflik laten karena belum adanya titik temu mengenai penetapan sistem zonasi kawasan TNBD.

Konflik vertikal baik yang bersifat manifest maupun laten sebagaimana digambarkan secara umum di atas akan memberikan pengaruh besar terhadap kelangsungan pengelolaan kawasan TNBD dan perlu diurai secara lebih rinci untuk memahami struktur konflik yang bersifat konprehensif.

\subsubsection{Kasus Konflik Kelompok Suku Anak Dalam atau Orang Rimba versus BKSDA Jambi}

Konflik Suku Anak Dalam atau Orang Rimba dengan pihak pengelola TNBS yang waktu itu masih di bawah 
BKSDA Jambi terjadi sekitar tahun 2007. Konflik berawal dari penolakan Suku Anak Dalam atau Orang Rimba terhadap rencana pengelolaan taman nasional bukit duabelas (RPTNBD). Konflik ini melibatkan beberapa kelompok Suku Anak Dalam atau Orang Rimba yaitu Temenggung Ngerip, Temenggung Majid, Temenggung Tarib, Temenggung Jelitai, dan Temenggung Pembubar, beberapa aktivis LSM yaitu dari Lembaga Sakola, Wahana Lingkungan Hidup (WALHI) Jambi, Perhimpunan Petani Jambi (PPJ), Perhimpunan Bantuan Hukum Indonesia (PBHI) Sumatera Barat, dan KKI WARSI Jambi, serta pemangku kebijakan TNBD yaitu BKSDA Jambi.

Bentuk perlawanan dilakukan Suku Anak Dalam atau orang timba melalui aksi-aksi demontrasi penolakan RPTNBD ke kantor gubernur Provinsi Jambi, Kantor DPRD Provinsi Jambi, Kantor Dinas Kehutanan Jambi. Konflik ini berakhir dengan sendirinya tanpa ada penyelesaian ketika terjadi pergantian rezim pengelola TNBD dari BKSDA Jambi ke Balai TNBD.

Pengelolaan TNBD dengan sistem zonasi merupakan pedoman bagi pihak balai TNBD sebagai sebuah kemutlakan yang menjadi amanat dari UU No.5/1990. Hal ini berarti bahwa setiap pemanfaatan ruang dalam kawasan TNBD harus mengacu pada sistem zonasi yang telah ditetapkan. Secara fisik, kawasan hutan TNBD sebagian besar sudah mengalami kerusakan baik dari aktivitas perusahaan HPH sebelumnya (karena sebagian besar kawasan TNBD adalah eks areal konsesi $\mathrm{HPH}$ ), aktivitas pembalakan liar oleh warga sekitar, dan aktivitas perladangan Suku Anak Dalam atau Orang Rimba (meskipun bukan faktor dominan). Hal ini berarti bahwa penetapan zona kawasan rehabilitasi kemungkinan menempati proporsi yang lebih luas dibandingkan dengan zona lainnya.

Dalam konsep zonasi yang ditetapkan disebutkan bahwa zona rehabilitasi tertutup untuk untuk semua kegiatan yang tidak ada kaitannya dengan program pemulihan lingkungan. Setelah proses intervensi berakhir, tipe zona untuk eks areal rehabilitasi akan disesuaikan dengan keperluan konservasi kawasan (Balai TNBD, 2007: 4). Dengan demikian diprediksi bahwa jika hal ini diterapkan jelas akan mempersulit ruang gerak Suku Anak Dalam atau Orang Rimba yang bermukim di dalam TNBD. Situasinya akan diperburuk lagi dengan penetapan daerah-daerah yang kondisi hutannya masih baik ke dalam zona-zona yang tidak membuka ruang bagi Suku Anak Dalam atau Orang Rimba, padahal daerah-daerah yang kondisi hutannya masih tergolong baik merupakan basis mata pencaharian Suku Anak Dalam terhadap hasil hutan non kayu, sampai di sini belum lagi kasus-kasus konflik warga sekitar dengan perusahaan-perusahaan di TNBD yang merupakan rumah bagi Suku Anak Dalam atau Orang Rimba.

\subsection{Dampak Konflik}

Akibat nyata dari konflik ini adalah jatuhnya dua orang korban dari pihak Suku Anak Dalam atau Orang Rimba dan beberapa warga desa yang terlibat konfrontasi mengalami lukaluka. Di samping itu warga desa telah mengalami kerugian material karena harus membayar denda adat sebanyak 2.500 lembar kain kepada kelompok Suku Anak Dalam atau Orang Rimba 
sebagaimana yang menjadi kesepakatan dari hasil perundingan.

Di sisi lain, penghapusan praktekpraktek pungutan terhadap warga desa yang melakukan eksploitasi terhadap sumber daya hutan mendorong proses percepatan degradasi sumber daya hutan karena sudah tidak ada lagi halangan bagi warga desa untuk mengambil kayu dihutan, dampak ini jelas bisa merugikan segala pihak: Pertama, mitos dan sakralnya sebuah hutan bagi Suku Anak Dalam atau Orang Rimba menjadi terkikis. Kedua, illegal logging jelas merusak lingkungan dan keasrian hutan, ketiga segala konflik sosial yang terjadi berakibat terhadap terjadinya percepatan laju penurunan sumber daya hutan dan hancurnya institusi lokal yang mengatur pola pemanfaatan sumber daya hutan.

Efek dari konflik yang berakhir pada bentrok fisik tersebut adalah hukum-hukum adat baik hukum adat yang dulu diterapkan oleh warga desa setempat maupun hukum adat yang ada pada masyarakat Suku Anak Dalam atau Orang Rimba, menjadi semakin lemah karena memang mereka tidak lagi begitu mentaati hukum adat yang berlaku. Warga desa setempat yang biasa melakukan illegal logging atau pembalakan liar, akhirnya menganggap bahwa kawasan tersebut adalah kawasan open acces, yang pada akhirnya jelas melahirkan ketegangan-ketegangan khususnya mereka yang ingin mengambil keuntungan dari hutan, dalam hal ini perusahaan sebagai pemegang $\mathrm{HPH}$ maupun Suku Anak Dalam atau Orang Rimba yang hidup serta mengembara di dalam hutan.

Akibat lain dari konflik ini adalah terjadinya disharmonisasi hubungan sosial antara warga desa dengan Orang Rimba yang dalam hal ini terkait dengan menurunnya modal sosial mereka melalui pemutusan hubungan perjenengan. Pasca konflik, jenang yang ada di desa sei ruan tidak lagi menjalankan fungsinya mengayomi Suku Anak Dalam atau Orang Rimba begitupun sebaliknya Orang Rimba tidak lagi menfungsikan jenang di desa sungai ruan ulu terutama dalam hal pemasaran hasil hutan (wawancara dengan Orang Rimba Zub).

\subsection{Dilema Suku Anak Dalam atau Orang Rimba di Tengah Tantangan Zaman}

Tidak bisa dipungkiri mewabahnya budaya-budaya luar yang masuk ke Indonesia khususnya di Jambi melalui media massa serta dunia maya sangat mempengaruhi eksistensi kebudayaan Suku Anak Dalam atau Orang Rimba. Meskipun proses saling mempengaruhi adalah gejala yang wajar dalam interaksi antar sesama masyarakat, dengan melalui interaksi tadi itulah antar kelompok masyarakat khususnya kebudayaan yang di Jambi saling dipengaruhi dan mempengaruhi termasuk kebudayaan Suku Anak Dalam atau Orang Rimba.

Masyarakat Jambi merupakan masyarakat yang majemuk dalam berbagai hal, seperti keanekaragaman budaya, lingkungan alam, dan wilayah geografisnya. Tentu kebudayaan lokal tersebut sekaligus menjadi tantangan untuk mempertahankan eksistensinya demi mewarikan kepada generasi selanjutnya. Kebudayaan Suku Anak Dalam atau Orang Rimba sebenarnya sanggat membanggakan karena memiliki keanekaragaman yang sangat bervariasi serta memiliki keunikan tersendiri. 
Terlepas dari itu tentu setiap daerah punya kebudayaan yang berbedabeda, khususnya kebudayaan Suku Anak Dalam atau Orang Rimba, dari perbedaan itulah yang menjadikan jati diri bangsa menjadi majemuk. Tapi jika kebudayaan ini memudar atau hilang maka bisa jadi jati diri dan khazanah kebudayaan nusantara juga bisa ikut hilang. Apalagi seiring berkembangnya zaman, menimbulkan perubahan pola hidup masyarakat yang lebih modern. Akibatnya, masyarakat lebih memilih kebudayaan baru yang mungkin dinilai lebih praktis dibandingkan budaya lokal seperti kebudayaan Suku Anak Dalam atau Orang Rimba.

Sampai di sini Suku Anak Dalam atau Orang Rimba bener-benar merasa terpojok, semua konflik diatas, baik konflik dilarangnya Suku Anak Dalam atau Orang Rimba melakukan aktivitas di kawasan hutan yang dilindungi oleh TNBD karena di khawatirkan bisa merusak ekosistem kawasan. Suku Anak Dalam atau Orang Rimba juga harus berhadapan dengan tantangan realitas zaman yang terus berubah akibat globalisasi dan perkembangan teknologi informasi.

Faktanya adalah akibat konflikkonflik diatas banyak Suku Anak Dalam atau Orang Rimba merasa kehilangan identitas, menjadi masyarakat biasa, berbaur dengan warga desa serta melakukan transaksi jual beli layaknya masyarakatbiasa, meskipun adabeberapa kelompok yang masih bertahan didalam kawasan hutan menjaga eksistensi mereka di tengah gempuran zaman.

\section{IV.SIMPULAN}

Dari penjelasan di atas dapat disimpulkan bahwa penyebab terjadinya konflik sosial dalam pemanfaatan sumber daya hutan di kawasan TNBD adalah beberapa hal. Pertama, adanya perbedaan persepsi mengenai klaim wilayah antara negara, perusahaan, Suku Anak Dalam atau Orang Rimba itu sendiri yang memang sudah lama mendiami hutan kawasan TNBD, kemudian warga desa sekitar. Kedua, adanya benturan kepentingan dalam pemanfaatan sumber daya hutan yang memang sebelumnya rumah atau tempat bagi Suku Anak Dalam atau Orang Rimba. Ketiga, adanya persaingan dalam pemanfaatan sumber daya hutan TNBD. Keempat, merupakan dilema bagi Suku Anak Dalam atau Orang Rimba ditengah perkembangan zaman. Tempat tinggal yang sudah lama mereka tempati terbentur dengan kebijakan-kebijakan yang berorientasi pada kepentingan kelompok bukan pada orang banyak.

Sebaiknya demi kepentingan bersama konflik tersebut segera diselaikan meskipun kadang tergolong masuk ke konflik kecil, tetapi gesekangesekan tersebut selalu ada dan lambat laun bisa menjadi besar dan merugikan berbagai pihak.

\section{UCAPAN TERIMA KASIH}

Terima kasih kepada pimpinan STIE Syari'ah Al-Mujaddid, Ketua LPPM, Wakil Ketua I dan II yang memberikan dukungan untuk penelitian dan riset ini, terima kasih juga kepada informan yang sudi meluangkan waktunya demi menunjang penelitian ini. 


\section{DAFTAR PUSTAKA}

Aritonang, 2005. R. Prospek Pengelolaan TNBD, Alam Sumatera NO. 8/Januari KKI Warsi.

Badan Pusat Statistik Provinsi Jambi. 2018.

Berkes, F. 1988. Common Properti Resources-Ekologi and Comunnity Based Sustainable Development, Belhaven Press A Division of Publishers London.

Creswell J. W, 2002. Research DesignQualitative and Quantitative Approaches. KKI Press Jakarta.

Dahrendof. R. 1963. Class and Class Conflik in Industrial Society, Stanford University Press, Stanford California.

Dharmawan A. H. 2006. Konflik Sosial dan Resolusi Konflik: Analisa Sosio-Budaya (Dengan Fokus Perhatian Kalimantan Barat). Makalah Seminar dan Lokakarya Nasional Pengembangan Perkebunan Wilayah Perbatasan Kalimantan.

Fahmi, Khairul. 2006. Rencana Pengelolaan Taman Nasional Bukit Dua Belas dan Hak Komunitas Orang Rimba Sebagai Salah Satu Masyrakat Adat, (Indegenious Peoole). Perhimpunan Bantuan Hukum dan Hak Azasi Manusia Indonesia (PBHI) Wilayah Sumatera Barat, dkk.

Gonner, C. 2001. Pengelolaan Sumber Daya di Sebuah Desa Dayak Benuaq: Stategi, Dinamika dan Prospek- Sebuah Studi Kasus dari Kalimantan Timur Indonesia. Deitche Geselischaft for Technishe Zumammenarbit (GTZ) Gmb H Eschborn, Germany.

Indriyanto, 2006. Ekologi Hutan, Bumi Aksara Jakarta.

Mitchell, B. Setiawan, B. Rahmi, 2007. Pengelolaan Sumber Daya dan Lingkungan, Gadjah Mada University Press.
Munawir, Muchlas. 1975. Sedikit Tentang Kehidupan Suku Anak Dalam (Orang Kubu) di Provinsi Jambi Provinsi Jambi.

Roshykin, 2005. Resolusi Konflik Sosial dan Lahan, PT. Finnantara Intiga Provinsi Kalimantan Barat. Makalah disampaikan dalam rangka Round Table Discussion Menyikapi Kasus Tenurial di Arial Hak Penguasaan Hutan, APHI-WG, 22 Febuari 2005.

Rozelin, Diana. 2014. Dialek Melayu Orang Rimba di Provinsi Jambi: Kajian Dialektologi, Universitas Sebelas Maret, Solo.

Sandbukt, Oyvind. 1984. Kubu Conception of Reality, Copenhagen, Scandinavia Institut of Asian Studies.

Scholten, L. Elsbeth. 1997. Sumatran Sultanate and Colonial State "Jambi and the Rise of Dutch Imprealism, 1830-1907", Southeast Asia Program, Cornel University, New York.

Sager, Steven. 2008. The Sky is our Roof, the Earth our Floor, Orang Rimba Customs and Religion in the Bukit Duabelas region of Jambi, Sumatera, Australian National Univesity, Australian.

Sutumo, Mutholib. 1995. Orang Rimbo, Kajian Struktural-Fungsional Masyarakat Terasing di Makekal Provinsi Jambi. Yogyakarta: Pustaka Pelajar.

Sentosa, Berlian. 2015. Resistensi Orang Rimba, "Studi tentang Perlawanan Orang Rimba Menghadapi Kebijakan Rencana Pengelolaan Taman Nasional Bukit Dua Belas Provinsi Jambi".

Warsi, 2005. Rencana Pengelolaan Taman Nasional Bukit Dua Belas (RPTNBD). Warung Informasi Konservasi (Warsi). 